\title{
Constraints to Effective Implementation of Elements of Special Education Curriculum in Teacher Preparation Programme in Nigeria: A Case Study of Colleges of Education
}

\author{
Eleri, N. O.E. \\ Nigerian Educational Research \& Development Council (NERDC), Abuja-Nigeria
}

\begin{abstract}
The need to empower pre-service teachers with knowledge and skills for teaching exceptional learners in regular classrooms led to the introduction of element of special education curriculum into the Nigerian teacher preparation programmes. The extent to which the curriculum is being implemented towards the achievement of its objectives has however, continued to raise concerns among educators. One of the problems is the fact that this curriculum is being implemented by unqualified lecturers. This study therefore, examined the constraints to effective implementation of elements of special education curriculum in colleges of education in Nigeria. The study adopted the expost-facto type of the descriptive survey design. Out of the 99 NCE awarding institutions in Nigeria, 98 institutions were purposively selected based on the single criteria that they do not offer special education as a major discipline. 217 lecturers teaching contents of element of special education were purposively selected for the study. One instrument was used in this study, that is: questionnaire on the problems of curriculum implementation (QOPCI) with a reliability index as 0.88 . Each of the institutions had an average of four experienced lecturers who were academically but not professionally qualified to teach elements of special education. Most of the required facilities were not available $(\bar{x}<1.50)$, not adequate $(\bar{x}=<1.50)$ and not utilized $(\bar{x}=<2.00)$. Most lecturers $(54.5$ to $96.3 \%)$ did not teach some of the specified content areas. Findings also showed that various aspects of classroom were ineffective (means range from 2.08 to 2.63).The weakness in the implementation of the elements of special education curriculum has been identified for the purpose of improvement. Towards effective special education teacher preparation in Nigeria, government should employ professionally qualified personnel and provide adequate facilities towards achievements of the objectives of the curriculum.
\end{abstract}

Keywords: Constraints, Implementation, Elements of Special Education, Teacher Prparation

\section{Introduction}

The introduction of the Universal Primary Education (UPE) in 1976 meant that every child of school going age would be in school. Although the program was free for a every Nigerian child but was never compulsory as compared to the Universal Basic Education (UBE) of today. This led to phenomenal increase in enrolment figure in the nation's primary school system (Eleri 2012). The awareness created by the introduction of the UPE therefore generated the much needed interest in western education. As the nations experienced astronomical increase in enrolment, so also more increases in the number of children with special educational needs in the system. The free Universal Primary Education created a situation whereby children with special needs were admitted into the regular school system. There was population explosion that posed a great challenge to teachers, parents, education authorities and policy makers. This situation gave cause for a rethink on how best to meet the challenges of children with special educational needs in the regular schools. However, the manpower requirement needed to cope with this new challenge was at this stage lacking.

The pressure of severe shortage of professional in special needs education and the mainstreaming of special needs learners, led to the integration of elements of special education into the regular teacher education program. The aim of this introduction was to ensure that every teacher will have some basic knowledge and skills of special needs education to use in the classroom.

Educating students with and without disabilities in the general education setting is becoming the current practice which is commonly known as inclusive education. Inclusive education is perceived to be one of the ways to increase educational access to large number of students with disabilities (Mukhopadhyay, Molosiwa and Moswela, 2009). This means more children with disabilities will be placed in the regular classroom than before. In order to provide effective, inclusive education for all students, teachers need to develop a different set of skills and knowledge than traditionally required by the profession (Mukhopadhyay et. al, 2009).

Schumm and Vaughn (1995) and Baker and Zigmond (1995), in separate studies, observed that increasing numbers of children with special needs are being served in the regular classrooms which is dramatically changing the way special education services are being provided in schools. They stressed that this development must be addressed in pre-service teacher education programme so that the next generation of 
educators will be better prepared to work more efficiently and effectively. Therefore, the importance of changing the traditional ways of teaching in regular classrooms cannot be overemphasized. Given the complex nature of classrooms and the increasing demands on teachers, who often have little or no specialized training in working with exceptional learners, structures should be set up to provide the necessary help and guidance for teachers to make changes in their instinct (Maag and Katsiyannis, 2000).

With the increasing diversity among children in today's classroom, teacher preparation programme are increasingly called on to train teachers who are able to respond competently to the challenges of inclusive classrooms (Munby, Lock, Hutchinson, Whitehead \& Martin, 1999). A major part of responding to the diversity found inside the classroom is through effective and efficient teacher preparation. Regular classroom teachers often feel that they are inadequately prepared to address the needs of learners with various categories of exceptionalities (Jenkins, Pateman \& Black, 2002). This calls for a change in the national teacher preparation program for teachers.

The purpose of teacher education according to the National Policy of Education (2007) is to provide teachers with the intellectual out professional background adequate for their assignments, and make them adaptable to any changing situations. Preparing quality teachers for inclusive education is a challenging task in both developed and less developed countries. The situation in Nigeria is not different form other countries. The policy of equal educational opportunities for all citizens as enshrine in the National Policy on Education (2007) gave the legal backing to the practice of inclusive education in Nigeria. Consequently, the National Policy on Education (NRE, 1977) in section 8 paragraph 56(4) provided the mandate for the integration of elements of special education into the curriculum of all teacher education programs in Nigeria.

The implementation of the elements of special education in the colleges of Education and indeed other institutions offering teacher training program was being done without envisaging possible problems. Even if the National Curriculum for Teachers' college did, such envisaged problems were not spelt out in the document. Considering the wide range of areas of exceptionality among students across the educational levels viz-a-vis; the gifted, the visually impaired, the hearing impaired, learners with intellectual disabilities, learning disabilities, and the speech and language impaired, the dearth of qualified specialized personnel to train all pre-service teachers becomes a challenge (Eleri, 2012). This paper therefore investigated the constraints to effective implementation of elements of special Education Curriculum in Teacher preparation program in country with particular reference to Colleges of Education in Nigeria.

\section{Purpose of study}

The objectives of this study are:

1. To determine the quality of lecturers teaching elements of special education in Colleges of Education.

2. To investigate the extent to which selected factors influence or hinder effective implementation of elements of special education.

\section{Research questions}

The following research questions will be answered in this paper.

1. What is the profile of the NCE-awarding institutions with respect to:

(a) lecturers' qualification and

(b) lecturers' experience?

2. What are the problems encountered by the lecturers' in the implementation of the Elements of Special Education Curriculum?

\section{Research Design}

\section{Methodology}

The study adopted the descriptive research method of the expost facto type. This was relevant in this study as the variables have all existed and were investigated as they were without any manipulation.

\section{Sample Selection}

Out of the 99 NCE-awarding institutions in Nigeria, 98 institutions were purposively selected based on the single criteria that they all offer general and specialized courses but do not offer special education as a major discipline. The only College of Education (Special) Oyo was left out in the selection. Also, all the lecturers teaching Elements of Special Education Curriculum as a course were purposively included in the study. These gave a total of 217 lecturers in all.

\section{Instruments}

The instrument tagged "Questionnaire on the Problems of Curriculum Implementation" (QOPCI) was designed and developed by the researcher. It was used to find out the particular problems which lecturers see as 
actually hindering the effective and smooth delivery of instructions as well as successful implementation of the curriculum. Section A covers socio-demographic information such as qualification and teaching experience were sought from the lecturers. Section B covers the problems found in literature as well as those envisaged by the curriculum designers as possible hindrances to the actualization of the objectives. This questionnaire was structured along the 3-point Likert scale of the Very Serious (VS), Serious (S) and Not Serious (NS) for items which have been rated as constituting problem by indicating "Yes" in the questionnaire. QOPCI was face- and content-validated by comparing the problems with those available in literature while peer and expert review was also carried out. Reliability was ascertained by computing Cronbach alpha having administered twenty copies to the lecturers who did not participate in the main study. This procedure gave 0.88 as the reliability index.

\section{Procedure for Data Collection}

The questionnaires were sent through postage to research assistants who are lecturers in the $98 \mathrm{NCE}$ awarding institutions in Nigeria. The research assistants helped to administer the questionnaires to their colleagues while they also completed their personal copies. The period of data collection lasted ten (10) weeks.

\section{Data Analysis}

Data were analyzed using frequency count, percentage, mean and standard deviation as well as bar chart. These were used to provide answers to research questions.

\section{Results}

Research Question 1a: What is the profile of the NCE-awarding institutions with respect to lecturers' qualification?

Table 1: Qualification of the Lecturers

\begin{tabular}{lcc}
\hline Qualification & Frequency & Percent \\
\hline Bachelor of Education & 48 & 22.1 \\
Bachelor of Science + PGDE $^{\mathrm{a}}$ & 8 & 3.7 \\
Master of Education $^{\mathrm{a}}$ & 86 & 39.6 \\
Master of Science + PGDE $^{\mathrm{a}}$ & 39 & 18.0 \\
${ }^{\text {b Ph.D. without Education }}$ & 16 & 7.4 \\
bPh.D. with Education & 20 & 9.2 \\
Total & $\mathbf{2 1 7}$ & $\mathbf{1 0 0 . 0}$ \\
\hline
\end{tabular}

Note: The subscript alphabets indications the following: $\mathrm{PGDE}^{\mathrm{a}}$ means postgraduate diploma in education. ${ }^{\mathrm{b}} \mathrm{Ph} . \mathrm{D}$ indicates Doctor of Philosophy.

Table 1 shows that majority of the lecturers hold the M.Ed. ( $\mathrm{N}=86 ; 39.65)$. In proportion, this group is followed by those with B.Ed. (N=48; 22.1\%). Also, 39 lecturers (18.0\%) hold the M.Sc. with PGDE. Those in the minorities are B.Sc. + PGDE $(\mathrm{N}=8 ; 3.7 \%)$, Ph.D without Education $(\mathrm{N}=16 ; 7.4 \%)$ and Ph.D with Education $(\mathrm{N}=20 ; 9.2 \%)$. These various categories are qualified except that the B.Ed. and B.Sc. + PGDE could be considered low for teaching in tertiary institutions such as NCE-awarding institutions.

Research Question 1b: What is the profile of the NCE-awarding institutions with respect to lecturers' experience?

Table 2: Years of Experience of the Lecturers

\begin{tabular}{lcc}
\hline Experience (years) & Frequency & Percent \\
\hline Below 5 & 41 & 18.9 \\
$5-10$ & 44 & 20.3 \\
$11-15$ & 36 & 16.6 \\
$16+$ & 96 & 44.2 \\
Total & $\mathbf{2 1 7}$ & $\mathbf{1 0 0 . 0}$ \\
\hline
\end{tabular}

Note: The subscript + means and above.

From Table 2, the highest proportion of lecturers have more than 16 years of teaching experience $(\mathrm{N}=96$; $44.2 \%)$ while $41(18.9 \%)$ have below 5 years. This implies that the level of experience of the teachers is at the upper side of the continuum. Hence, their quality of teaching is expected to be effective.

Research Question 2: What are the problems encountered by the lecturers' in the implementation of the Elements of Special Education Curriculum? 
Table 3. Problems Encountered by Lecturers in Implementing the Curriculum

\begin{tabular}{|c|c|c|c|c|c|c|c|}
\hline \multirow[b]{2}{*}{ SN } & \multirow[b]{2}{*}{ Factors } & \multirow[b]{2}{*}{ Yes } & \multicolumn{3}{|c|}{ Extent } & \multirow{2}{*}{ Mean } & \multirow{2}{*}{$\begin{array}{l}\text { Std } \\
\text { Dev }\end{array}$} \\
\hline & & & $\begin{array}{c}\text { Very } \\
\text { Serious } \\
\mathbf{3}\end{array}$ & $\begin{array}{c}\text { Serious } \\
2\end{array}$ & $\begin{array}{c}\text { Not } \\
\text { Serious } \\
1\end{array}$ & & \\
\hline 1 & $\begin{array}{l}\text { Students apathy to Special } \\
\text { Education }\end{array}$ & $\begin{array}{c}70 \\
(32.3)\end{array}$ & $\begin{array}{c}8 \\
(11.4)\end{array}$ & $\begin{array}{c}20 \\
(28.6)\end{array}$ & $\begin{array}{c}42 \\
(60.0)\end{array}$ & 1.51 & 0.41 \\
\hline 2 & Dearth of qualified lecturers & $\begin{array}{c}55 \\
(25.3)\end{array}$ & $\begin{array}{c}4 \\
(7.2)\end{array}$ & $\begin{array}{c}10 \\
(18.2)\end{array}$ & $\begin{array}{c}41 \\
(74.6)\end{array}$ & 1.32 & 0.23 \\
\hline 3 & $\begin{array}{l}\text { Poor experience on the part of } \\
\text { lecturers }\end{array}$ & $\begin{array}{c}36 \\
(16.6)\end{array}$ & $\begin{array}{c}4 \\
(11.0)\end{array}$ & $\begin{array}{c}3 \\
(8.3)\end{array}$ & $\begin{array}{c}29 \\
(80.6)\end{array}$ & 1.31 & 0.31 \\
\hline 4 & $\begin{array}{l}\text { Students' lack of interest in } \\
\text { Special Education }\end{array}$ & $\begin{array}{c}78 \\
(35.9) \\
\end{array}$ & $\begin{array}{c}12 \\
(15.4)\end{array}$ & $\begin{array}{c}30 \\
(38.5) \\
\end{array}$ & $\begin{array}{c}36 \\
(46.1) \\
\end{array}$ & 1.69 & 0.18 \\
\hline 5 & $\begin{array}{l}\text { Society's negative attitude to } \\
\text { disable people }\end{array}$ & $\begin{array}{c}126 \\
(58.1)\end{array}$ & $\begin{array}{c}50 \\
(39.7)\end{array}$ & $\begin{array}{c}28 \\
(22.2)\end{array}$ & $\begin{array}{c}48 \\
(38.1)\end{array}$ & 2.01 & 0.12 \\
\hline 6 & $\begin{array}{l}\text { Students level of seriousness is } \\
\text { low }\end{array}$ & $\begin{array}{c}94 \\
(43.3) \\
\end{array}$ & $\begin{array}{c}20 \\
(21.3) \\
\end{array}$ & $\begin{array}{c}12 \\
(12.8) \\
\end{array}$ & $\begin{array}{c}62 \\
(65.9) \\
\end{array}$ & 1.55 & 0.14 \\
\hline 7 & $\begin{array}{l}\text { Lack of facilities and } \\
\text { equipment }\end{array}$ & $\begin{array}{c}154 \\
(71.0) \\
\end{array}$ & $\begin{array}{c}81 \\
(52.6) \\
\end{array}$ & $\begin{array}{c}33 \\
(21.4) \\
\end{array}$ & $\begin{array}{c}40 \\
(26.0) \\
\end{array}$ & 2.27 & 0.31 \\
\hline 8 & High cost of Equipment & $\begin{array}{c}154 \\
71.0)\end{array}$ & $\begin{array}{c}80 \\
(51.9)\end{array}$ & $\begin{array}{c}30 \\
(19.5)\end{array}$ & $\begin{array}{c}44 \\
(28.6)\end{array}$ & 2.23 & 0.28 \\
\hline 9 & Lack of funds & $\begin{array}{c}154 \\
(71.0) \\
\end{array}$ & $\begin{array}{c}78 \\
(50.6) \\
\end{array}$ & $\begin{array}{c}28 \\
(18.2) \\
\end{array}$ & $\begin{array}{c}48 \\
(31.2) \\
\end{array}$ & 2.19 & 0.12 \\
\hline 10 & Ineffective teaching methods. & $\begin{array}{c}40 \\
(18.4)\end{array}$ & $\begin{array}{c}5 \\
(12.5)\end{array}$ & $\begin{array}{c}6 \\
(15.0)\end{array}$ & $\begin{array}{c}29 \\
(72.5)\end{array}$ & 1.40 & 0.33 \\
\hline
\end{tabular}

Table 3 shows that identified problems are lack of facilities and equipment $(\mathrm{N}=154 ; 71.0 \%)$, high cost of equipment $(\mathrm{N}=154 ; 71.0 \%)$ lack of funds $(\mathrm{N}=154 ; 71.0 \%)$ and society's negative attitude to people with special needs $(\mathrm{N}=126 ; 58.1 \%)$. More than fifty per cent of the lecturers ticked these problems. Further, out of all the listed problems, lack of facilities and equipment is the most serious $(\bar{x}=2.23 ; \mathrm{SD}=0.31)$ followed by high cost of equipment $(\bar{x}=2.23 ; \mathrm{SD}=0.28)$, lack of funds $(\bar{x}=2.19 ; \mathrm{SD}=0.12)$ and society's negative attitude to people with special needs $(\bar{x}=2.01 ; \mathrm{SD}=0.12)$. Also of serious magnitude are students' lack of interest in special education $(\bar{x}=1.69 ; \mathrm{SD}=0.18)$, students' low level of seriousness $(\bar{x}=1.55 ; \mathrm{SD}=0.14)$ and students' apathy to Special Education $(\bar{x}=1.51 ; \mathrm{SD}=0.41)$. All the others are not serious problems confronting the implementation of the curriculum.

The intensity of these problems are represented in figure 1.

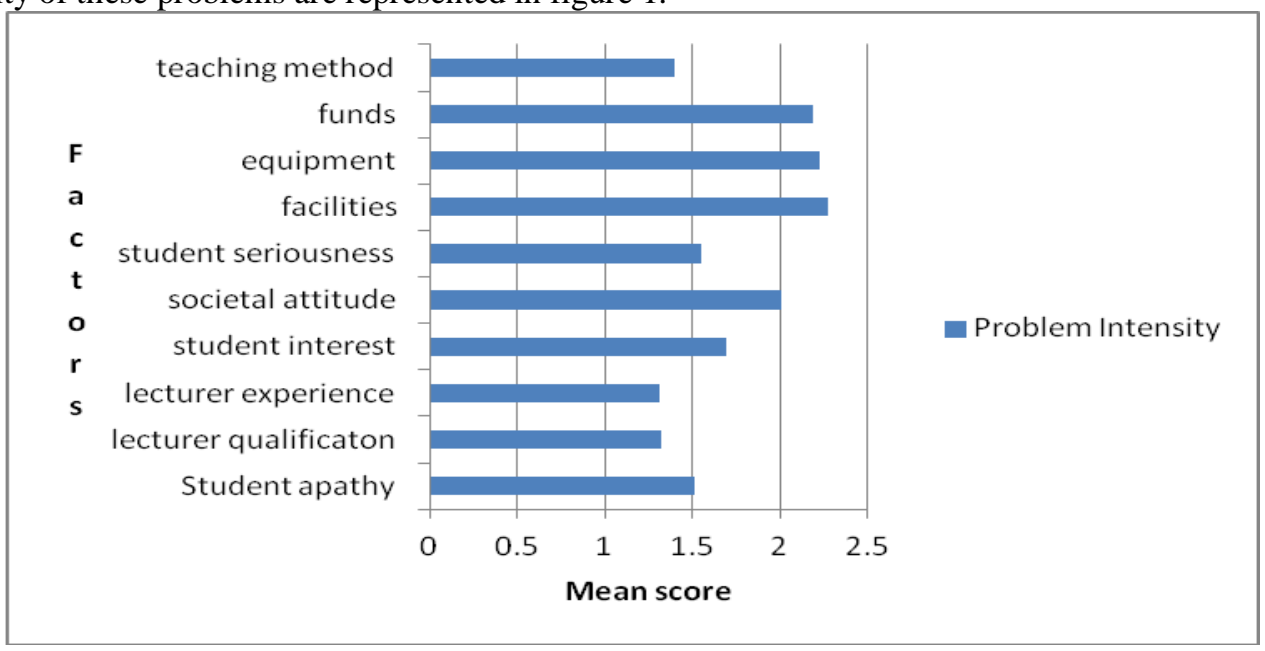

Figure 1: Levels of Intensity of the Listed Problems

\section{Discussion}

It was found that the lecturers were mostly academically qualified. This present finding on the qualification of the personnel who teach in these institutions sampled was contrary to the finding of Boe and 
Cook (2006) as well as Billingsloy, Fall and Williams (2006) which revealed high percentage of uncertified educators staffing special education institutions in the USA. This was a development which was cheery in spite of the fact that the academic qualifications of many of them is not directly in special education. Indeed, some of them studied such education courses as: Education Psychology, Guidance and Counseling, Educational Management and the likes. These lecturers were appointed and assigned the course with the unjustifiable assumption that they could teach special education effectively. This could lead to the situation where topics which are technical or beyond the level of the teacher would be left untaught with attendant poor students' performance in the course. This finding corroborates the reports of Trait and Purdie (2000), Cook (2001) and Praisner (2003) who all berated poor qualification of personnel in Special Education

However, this phenomenon should be looked into by the Federal Government of Nigeria because of the importance attached to using teachers who are qualified to teach learners (Betta, Zau and Rice, 2003, Hannshek et al. 2002). Further, allowing this scenario outlined by the present study to continue has the capacity of jeopardizing the government's noble intentions for establishing these institutions. This is because, it has been reiterated by researchers (Rockoff 2004, Aaronson, Barrow and Sander,. 2007) that the logical starting point for any policy to address the achievement of students with special needs is the quality of teachers instructing them.

\section{Conclusion and Recommendations}

This study has shown that in spite of the high levels of qualification of the lecturers and the associated length of years of teaching experience, all the factors isolated from literature were rated as constituting constraints to the effective implementation of elements of special education curriculum in Nigeria Colleges of Education. Based on this, the following recommendations were made:

- Government should release adequate funds for the procurement of equipment and facilities necessary for effective implementation of Elements of Special Education Curriculum in the Colleges;

- Government and non-governmental organizations should sensitize the public in order to help change the negative societal attitudes to people with special needs and subsequently improve their attitudes to Special Education;

- NCE education students who are pre-service in Nigerian schools should be assisted through innovative strategies to develop more interest in Special Education as well as improved level of seriousness in their study of the course.

\section{References}

[1]. Aaronson, D., L. Barrow, and W. Sander 2007 "Teachers and student achievement in the Chicago public high schools", Journal of Labor Economics, 25(1), 95-135.

[2]. Baker, J. \& Zigmond, N. 1995. The meaning and practice of inclusion for students with learning disabilities: Themes and implications from the five cases. Journal of Special Education, 29 (2), 163-180.

[3]. Betts, J. R., Andrew, C. Z., and Lorien A. R., 2003. "Determinants of Student Achievement: New Evidence from San Diego." San Diego, CA: Public Policy Institute of California.

[4]. Billingsley, B., Anna-Maria, F., \& Thomas, O. W. 2006. Who is Teaching Students with Emotional Disorders? A Profile and Comparison to Other Special Educators. Behavioral Disorders, 31(1), 252-64.

[5]. Boe, E. E., \& Cook, H. L. 2006. "The Chronic and Increasing Shortage of Fully Certified Teachers in Special and General Education." Exceptional Children, 72(4), 443-60.

[6]. Cook, B. 2001. A Comparison of Teachers' Attitudes toward Their Included Students with Mild and Severe Disabilities. The Journal of Special Education, 34(4), 203-213.

[7]. Eleri, N.O. E 2012. Evaluation of Implementation of Elements of Special Education Curriculum in NCE-Awarding Institutions in Nigeria. Unpublished Ph.D. Thesis University of Ibadan, Ibadan.

[8]. Federal Republic of Nigeria, 2004. National policy on education. Lagos: NERDC Press.

[9]. Federal Republic of Nigeria, 2007. National policy on education (Draft). Lagos: NERDC Press.

[10]. Hanushek, E. A., Kain, J. F., \& Rivkin, S. G. 2002. "Inferring Program Effects for Specialized Populations: Does Special Education Raise Achievement for Students with Disabilities? Review of Economics and Statistics, 84(4), 584-99.

[11]. Jenkins, A. A., Pateman, B., \& Black, R. 2002. Partnerships for dual preparation in elementary, secondary, and special education programs. Remedial and Special Education, 23(6), 359-371.

[12]. Maag, J. W., \& Katsiyannis, A. 2000. Recent legal and policy developments in special education. NASSP Bulletin, 84(613), 1-8.

[13]. Mukhopadhyay, S., Molosiwa, S. M. \& Moswela, E. 2009. Teacher Trainees' Level of Preparedness for Inclusive Education in Botswana Schools: Need for Change. International Journal of Scientific Research in Education, Vol. 2(2), 51-58. Retrieved [13/03/2013] from http://www.ijsre.com.

[14]. Munby, H., Lock, C., Hutchinson, N.L., Whitehead, L.E., \& Martin, A.K. 1999. Evaluation by teacher candidates of a field-based teacher education program using focus groups. Teacher Education Quarterly, Spring, 26(2), pp. 35-50.

[15]. Praisner, C. 2003. Attitudes of Elementary School Principals toward the Inclusion of Students with Disabilities. Council for Exceptional Children, 69(2), 135- 145.

[16]. Rockoff, J. E. 2004. The Impact of Individual Teachers on Student Achievement: Evidence from Panel Data. American Economic Review, 94(2), 247 - 252.

[17]. Schumm, J. S., Vaughn, S. 1995. Getting Ready for Inclusion: is the stage set? Learning Disabilities Research \& Practice, 10(169179).

[18]. Tait, K., \& Purdie, N. 2000. Attitudes toward Disability: Teacher Education for Inclusive Environments in an Australian University. International Journal of Disability, Development and Education, 47(1), 25-38. 